\title{
Assessment of Run-off and Soil Loss under different Land-use Practices in a Himalayan Watershed, India
}

\author{
Dr. Prabuddh Kumar Mishra \\ Assistant Professor, Department of Geography, Shivaji College, University of Delhi. \\ prabuddh@shivaji.du.ac.in
}

Abstract: Soil erosion is a serious threat to counter global population growth with increased and sustainable agricultural production. Soil erosion is a crucial problem in Sikkim Himalaya where mountains and still tectonically active. Although deforestation, overgrazing and intensive agriculture, due to population pressure, have caused accelerated erosion, natural phenomena inducing erosion, such as exceptional rains and earthquakes, flooding in the high Himalayas are also common. In this context information on the effectiveness of soil and water conservation (SWC) measures was collected from field experiment in the Papung-Ben Khola watershed of Sikkim Himalaya. The overland flow and soil loss were estimated from 5 experimental plots under each type of conservation practices during 2009-2010 in monsoon seasons. These were estimated using natural shallow surface run-off and artificially delineated plots following Singh et al., (1983); Rai and Sharma (1998); and Sharma et al., (2001). The delineated plot size was $3 \times 3 \mathrm{~m}$ for estimations of overland flow and soil loss, and three plots were laid in each type of conservation practices

Results provided by running a soil erosion assessment method overland flow was recorded to be highest in open land/barren land (1.34\%). Among other land-uses the lowest overland flow was observed in large cardamom based agroforestry (1.08\%), followed by terrace cultivation (1.10\%), mandarin based agroforestry (1.11\%) and mixed cropping ranked the top (1.21\%) in the watershed. Overland flow varies in different types of SWC practices depending on their capacity to stand against the erosional power of rainfall. This paper deals with assessment of run-off and soil loss under different land-use practices in the watershed.

Keywords: Soil erosion, Overland flow, Run-off, Land-use, Sikkim Himalaya.

\section{INTRODUCTION}

Soil erosion is a major cause of environmental and agricultural problem worldwide. Although erosion has occurred throughout the history of agriculture, it has intensified in recent years (Pimentel et al., 1995). Worldwide, about $12 \times 10^{6}$ ha of arable land are destroyed and abandoned annually because of non-sustainable farming practices and only $1.5 \times 10^{9}$ ha of land are being cultivated (Pimentel et al., 1995). Land resource degradation in the Himalayan region is mainly caused by landslides, mudslides, collapse of man-made terraces, soil loss from steep slopes and decline of forest/pasture areas (ICIMOD, 1994). In the world map on the status of human-induced soil degradation, deforestation, removal of natural vegetation and overgrazing are reported to be the main reasons for loss of topsoil and terrain deformation due to soil erosion in the mountainous regions (UNEP/ISRIC, 1990). Sediment losses from undisturbed forests and agricultural land vary with the soils, geology, vegetation, watershed size and season of the year. Effective ground cover of undisturbed forest floors and vegetative covers dissipates much of the raindrop energy and promotes high rates of infiltration. Generally, soil loss under these conditions is very low (Patric, 1976). However, about $80 \%$ of the sediments to the world's oceans each year come from Asian rivers and amongst these the Himalayan rivers are the major contributors (Stoddart, 1969). 
The Himalaya contributes 500-1000 mg/ $\mathrm{km}^{2} / \mathrm{yr}$ of sediments (Milliman and Meade, 1983) and Sikkim in the eastern Himalaya is no exception, contributing as much as $616 \mathrm{mg} / \mathrm{km}^{2} / \mathrm{yr}$ (Rai and Sharma, 1998).

Soil and water are widely recognized as very important resources in the Himalayan region. Over the past 40 years, significant concerns have been raised over the degradation of the soil resource in the Sikkim Himalaya as a result of the expansion of agricultural land and the increase in cropping intensity. Management practices increase the potential for sediment production through soil alteration and disturbance of the protective cover of the forest ground. It has been demonstrated that superficial soil compaction and destruction may cause an increase in overland flow and, therefore, in soil losses (Mersereau and Dyrness, 1972; Blackburn et al., 1986; Moffat, 1991; Sidle and Hornbeck, 1991). The impacts of conservation on agricultural production are complex and highly situation specific. Valuation of the impacts of soil and water conservation (SWC) can be divided into those experienced on the land from which the soil is lost ("on-site") and those experienced elsewhere (offsite effects). Usually, only direct or on-site costs and benefits of soil conservation are included in cost-benefit analysis, based on costs and benefits as accruing to the individual farmer responsible for the damage, but not off-site costs and benefits affecting other individuals or parts of the society (Valdes, 1994).

Furthermore, there is a wide-spread concern about the threat of soil erosion, decreasing agricultural production, and a possible decline in food security, in many rural areas in less developing countries (LDCs). Therefore, initiatives have been taken to prevent soil erosion and to promote sustainable agriculture by introducing soil and water conservation. Programmes on resource conservation and sustainable agriculture were initiated to induce farmers to manage their land in a sustainable way. The justification of these programmes is that without external intervention farmers will not invest in SWC. Even if SWC practices are profitable, this is not a guarantee for adoption, as other factors may prevent a farm household from adopting a new technology (Lutz et al., 1994). The profitability of SWC practices is sensitive to key bio-physical and economic variables, such as initial soil conditions, discount rates and the effects of SWC on long term productivity (Antle et al., 2004). Programmes promoting SWC often rely on incentives to attract farmers and motivate them to implement SWC practices. However, the criticism of these programmes is that the SWC practices they promote are often not maintained. As soon as the support ends, farmers abandon the SWC practices because they were not really interested in these practices, as these interfere with current agricultural practices and lowers short-term agricultural output and profit (Winters et al., 2004).

In a reversal of their previous positions, many specialists and policy makers now acknowledge that the 'topdown' approach to soil and water conservation programmes has not worked with small-scale farmers in the tropics. Land degradation continues unabated, and a new strategy is urgently required if this massive problem is to be confronted. Soil conservation experts now concede that they can learn much from local land users themselves. Indeed the need to study and appreciate the approaches and strategies of local farmers has been increasingly articulated since the early 1980s (Chambers, 1983; Collinson, 1984; Richards, 1985; Willcocks, 1986; Chambers, et al., 1989; Warren, 1991; Pretty and Shah, 1994). This was translated into soil conservation terms for sub Saharan Africa (Reij et al., 1986) and the potential of indigenous measures in that region has been examined by Hailu and Runge-Metzer (1993). The theme has been echoed by Kerr and Sanghi (1992) for the semi-arid regions of India and Sharma et al., (2001) for the Sikkim Himalaya. However, the level of knowledge about indigenous soil and water conservation and, specifically, how it can be used in project design is still rudimentary. This chapter analyzes the effectiveness of indigenous SWC practices, examine the ways in which erosion reduces soil fertility and crop productivity, and compare various soil and water conservation practices and techniques that reduce erosion and help conserve water and soil resources. 


\section{EROSION ON LAND-USE/COVERS}

Worldwide review of the world's agriculture land, about $1 / 3^{\text {rd }}$ is devoted to crops and remaining $2 / 3^{\text {rd }}$ is devoted to pasture for livestock grazing. About $80 \%$ of the world's agricultural land suffers moderate to severe erosion, and $10 \%$ suffers slight to moderate erosion. Croplands are most susceptible to erosion because their soil is repeatedly tilled and left without a protective cover of vegetation. More than half of the world's pasturelands are overgrazed and subject to erosive degradation (Pimentel et al., 1995).

Soil erosion rates are highest in Asia, Africa, and South America, averaging 30 to 40 tons ha- $\mathrm{yr}^{-1}$ and lowest in USA and Europe, averaging 17 tons $\mathrm{ha}^{-1} \mathrm{yr}^{-1}$. Erosion rates are undisturbed forests range from only 0.004 to 0.05 tons ha $^{-1} \mathrm{yr}^{-1}$ (Pimentel et al., 1995). Soil erosion increases dramatically on steep slopes because steep slopes are now routinely being converted from forests for agricultural use due to increasing needs of the human population and land degradation. Loss of vegetative cover is particularly widespread in many third-world countries. About $60 \%$ of crop residues in China, and $90 \%$ in Bangladesh are removed and burned for fuel each year. The Hindu-Kush Himalayan region is also facing the same problem.

In the Himalayan region, very few studies have been conducted on land-use and soil erosion. Studies on natural watershed (i,e., without any alteration in land-use/cover) are many. The most revealing study is Lesser Himalaya and Shiwalik watersheds (Valdiya and Bartarya, 1989) emphasized that increased magnitude of soil loss and run-off was due to anthropogenic pressure, deforestation and road cutting etc. The mean soil loss was estimated to be about 2tons/ha/yr. They concluded that deforestation and agricultural activities have reduced the water yield by 50\% in the area (Rawat and Rawat, 1994). The Two studies conducted in Garhwal Himalaya revealed that the mean suspended loss was 9.13 and 4.69tons/ha/yr (Joshi et al., 1999). In Mamlay watershed of Sikkim Himalaya, among five micro-watersheds of different land-uses, run-off and sediment loss were highest in cropped area and lowest for forest dominated area. Soil loss from different micro-watershed was found range from 0.18 to 5.71 tons/ha/yr (Rai and Sharma, 1998).

The importance and efficiency of indigenous SWC practices have very often been ignored or underestimated by development agents, researchers, soil conservationists and government staff (IFAD, 1992). Although the objectives of knowing indigenous SWC practices give us an understanding of farmers' way of thinking about the measures (Hudson, 1992). In order to prevent the problem of soil erosion farmers of Papung-Ben Khola watershed used a number of indigenous SWC practices which are sustainably managing their land and food security.

\section{The STUdy AREA}

The Papung-Ben Khola watershed is located in the southern part of Sikkim State i.e. south district (Fig.1). The watershed is one of the most populated zone of the Sikkim. The geographical co-ordination of the watershed is $27^{\circ} 13^{\prime} 34^{\prime \prime}$ to $27^{\circ} 1^{\prime} 12^{\prime \prime} \mathrm{N}$ and $88^{\circ} 22^{\prime} 18^{\prime \prime}$ to $88^{\circ} 27^{\prime} 15^{\prime \prime}$ E. It has an elevation range of $326-2600 \mathrm{~m}$ above mean sea level and covers an area approximately $27.77 \mathrm{~km}^{2}$. The slope in the higher ranges exceeds more than $70 \%$. The watershed is fairly representative of conditions of the middle-mountains in the Himalaya. It is a rain-fed agrarian watershed having about 12 settlement blocks/villages.

The total population of the watershed was 12,451 in 2011 census with an average density of 448 person/ $\mathrm{km}^{2}$. There are two perennial streams (PapungKhola and Ben Khola) forming two micro-watersheds and other small streams are Daring Khola, SipsuKhola and Ringpi Chu are seasonal. Watershed drains into river Teesta. The watershed has a dendritic pattern and there is a strong traditional agro-forestry base in the watershed. The 
total forest area accounts about $48 \%$ of the total area of the watershed against $46 \%$ in the state. A study of the spatial distribution pattern of land-use/cover map clearly indicates the predominance of forest land in the upper and middle ecological zone and the presence of open forest throughout the watershed. Surface water and underground water is abundant during the monsoon season while it gets scarce in lean and winter seasons.

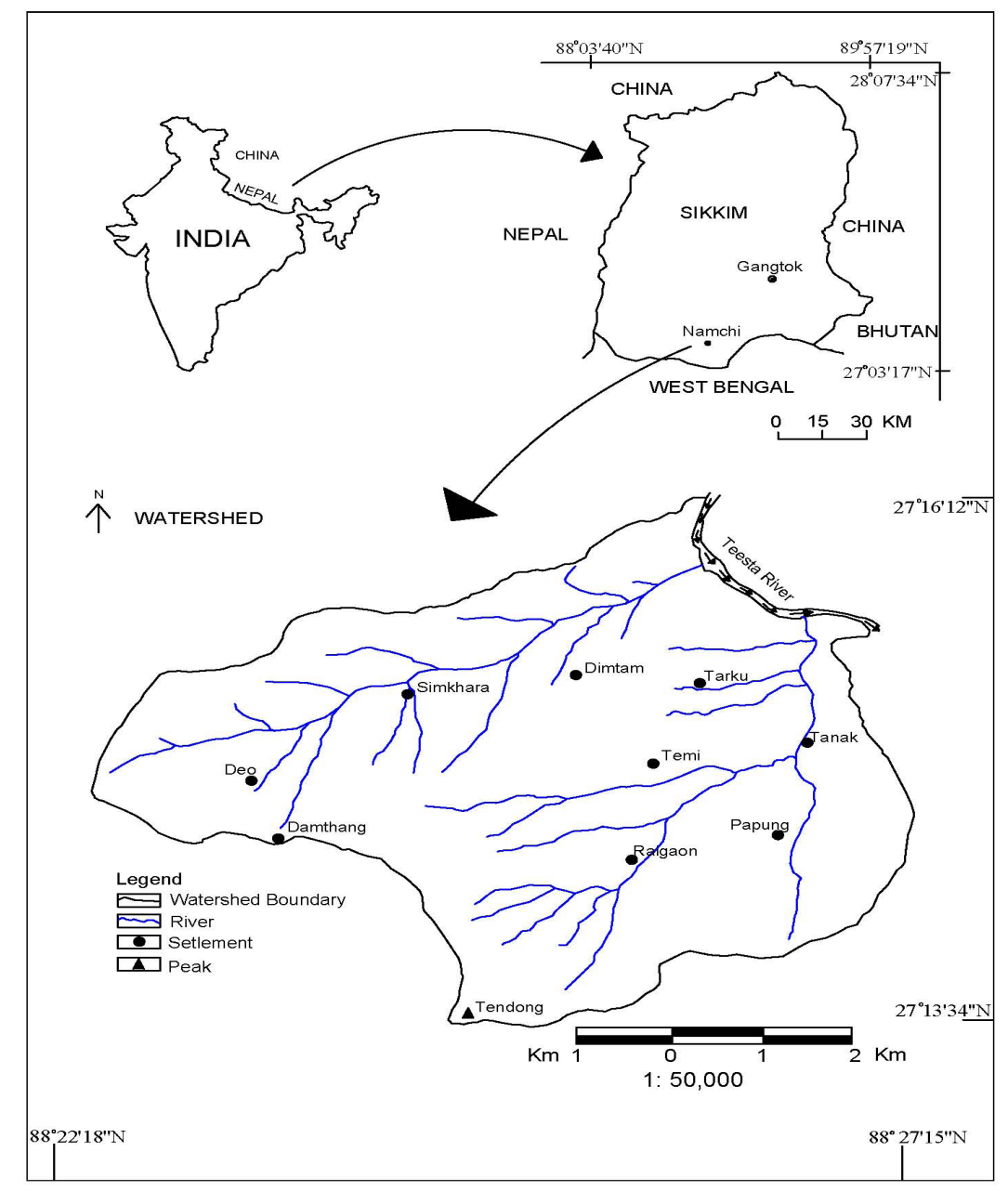

Fig1. Location map of Papung-Ben Khola watershed showing drainage pattern and settlements in Sikkim Himalaya

\section{Materials AND Methods}

Information on the effectiveness of soil and water conservation (SWC) measures were collected from field experiment in the watershed. The overland flow and soil loss were estimated from 5 experimental plots under each type of conservation practices during 2009-2010 in monsoon seasons. These were estimated using natural shallow surface run-off and artificially delineated plots following Singh et al., (1983); Rai and Sharma (1998); and Sharma et al., (2001). The delineated plot size was $3 \times 3 \mathrm{~m}^{2}$ for estimations of overland flow and soil loss, and three plots were laid in each type of conservation practices. These plots were delineated with aluminum sheets (inserted in soil for about $6 \mathrm{~cm}$ and remaining $15 \mathrm{~cm}$ exposed in the air) from all sides to prevent water likely to enter from adjacent areas. These plots were selected with $25^{\circ}$ to $30^{\circ}$ slopes in all the conservation 
practices as majority of the area of the watershed fall in this slope category. The overland flow and soil loss along the slope were estimated from the collecting tank after each rainfall event. Total precipitation was also recorded for the same time when the plots were put in the different SWC measures, so that the soil loss at the time of precipitation can be estimated. The eroded soil was sampled in the form of bed-load sediments and suspended clay materials from the collecting tank. The suspended clay material was separated by filtration through Whatman filter paper from the sample water. Total area of each sub-divided land-use in the watershed was calculated, and overland flow and soil loss from each of the land-use were estimated.

In these experiments the physical effectiveness of bench terrace, grass strips, large-cardamom and mandarin based agroforestry practices were compared with and without conservation situation with regards to retention of soil, retention of water and increase in crop yields. Additional information on the physical effectiveness of SWC measures were calculated from household survey. Discussions with extension staff in the field of SWC and with farmers, who are practicing the SWC measures were used to verify, update and collect some missing information from the reports.

\section{OvERLAND FLOW AND SOIL LOSS}

In most areas, raindrop splash and sheet erosion are the dominant form of erosion. Erosion is intensified in sloping land, where more than half of the soil contained in the splashes is carried downhill. Overland flow (percentage of rainfall during the rainy season for the same period) was recorded to be highest in open land/ barren land (1.34\%) where there was no vegetation or grasses were found and it was prone to erosion in the rainy season. Among other land-uses the lowest overland flow was observed in large cardamom based agroforestry (1.08\%), followed by terrace cultivation (1.10\%), mandarin based agroforestry $(1.11 \%)$ and mixed cropping ranked the top (1.21\%) in the watershed (Table. 1). Overland flow varies in different types of SWC practices depending on their capacity to stand against the erosional power of rainfall. Usually the non-forested sites had a greater overland flow of water compared with adjacent forested and agroforestry sites (Sharma et al., 2000).

When it was focused on the soil loss, it was observed that soil loss is directly proportional to overland flow. The data revealed that the soil loss followed the rate of overland flow. The results on the soil loss provide sufficient evidence that the indigenous soil and water conservation measures are effective in reducing soil loss compared to without SWC situation. Soil loss was estimated highest for the large cardamom based agroforestry $210 \mathrm{~kg} \mathrm{ha}^{-1}$

$\mathrm{yr}^{-1}$ followed by barren land, mixed cropping, mandarin based agroforestry and terrace cultivation (Table 1) due to steep slope of the landscape where large cardamom has been cultivated.

Table1. Overland flow and soil loss during the rainy season in the selected site under different soil and water conservation measures in the watershed

\begin{tabular}{|l|c|c|c|}
\hline Indigenous SWC practices & $\begin{array}{c}\text { Overland flow } \\
\text { (\% of rainfall) }\end{array}$ & $\begin{array}{c}\text { Soil loss } \\
\text { (kg/ha) }\end{array}$ & $\begin{array}{c}\text { Soil loss } \\
\text { (kg/ha/yr) }\end{array}$ \\
\hline Mixed cropping & 1.21 & 2.201 & 67.665 \\
\hline Barren land & 1.34 & 2.381 & 71.972 \\
\hline Terrace cultivation & 1.10 & 1.305 & 39.447 \\
\hline Cardamom based agroforestry & 1.08 & 6.963 & 210.449 \\
\hline Mandarin based agroforestry & 1.11 & 1.878 & 56.775 \\
\hline
\end{tabular}


American Research Journal of Humanities and Social Sciences (ARJHSS)

Table2. Water and soil run-off quantities and conservation values. The average rainfall for three events was 107 liters $/ \mathrm{m} 2$

\begin{tabular}{|l|c|c|c|c|}
\hline Plot type & Water runoff (liter) & Soil loss (kg) & $\begin{array}{c}\text { CV for water } \\
(\%)\end{array}$ & CV for soil (\%) \\
\hline Maize & $25 \pm 4$ & $1.51 \pm 0.18$ & 69 & 56 \\
\hline Finger-millet & $18 \pm 3$ & $1.32 \pm 0.14$ & 78 & 62 \\
\hline Mixed-cropping & $12 \pm 3$ & $0.95 \pm 0.12$ & 85 & 73 \\
\hline Large cardamom & $15 \pm 3$ & $0.45 \pm 0.06$ & 81 & 87 \\
\hline Broom grass & $10 \pm 2$ & $0.41 \pm 0.07$ & 88 & 88 \\
\hline Bare land & $80 \pm 11$ & $3.46 \pm 0.35$ & - & - \\
\hline
\end{tabular}

Values for water and soil runoff are mean \pm 1 SE based on three rainfall events.

CV: Conservation value (Based on: Sharma et al., 2001)

\section{Water and Soil Conservation Values}

Five dominant crop/vegetation covers have been assessed to determine the in situ soil and water conservation values in the watershed. These were: (i) maize; (ii) finger-millet; (iii) mixed cropping; (iv) large cardamom; and (v) broom grass. Water run-off, soil erosion, water conservation and soil conservation of the four are compared (Table 2). The highest runoff and soil loss was recorded in maize. Water runoff is reduced by less than onethird, and soil loss by two-fifths, in maize cultivation as compared to bare land (Table 2). Mixed cropping, large cardamom and broom grass showed fairly lower runoff compared to bare land and maize cultivation. Conservation value of water was high in mixed cropping, large cardamom and broom grass, while the soil conservation value was high only in large cardamom and broom grass plots. Soil loss was substantially lower in large cardamom and broom grass, and high water and soil conservation values suggest that they are of value both in economic and ecological terms (Sharma et al., 2001).

\section{Erosion and Productivity}

Erosion by water adversely affects soil quality and productivity by reducing infiltration rates, water-holding capacity, nutrients, organic matter, soil biota and soil depth. Each of these factors influences soil productivity individually but also interacts with other factors, making assessment of the impacts of soil erosion on productivity difficult. All crops require enormous quantities of water for their growth and the production of fruits. For example, during as single growing season, a hectare of corn (yield $7000 \mathrm{~kg} \mathrm{ha}^{-1}$ ) transpires about $4 \times 10$ ${ }^{6}$ liters of water and an additional $2 \times 10^{6}$ liters ha $^{-1}$ concurrently evaporates from the soil (Pimentel et al., 1995).

When erosion occurs, the amount of water runoff increases, so that less water enters the soil matrix and become available for the crop. Moderately eroded soil absorbs from $10 \mathrm{~mm}$ to $300 \mathrm{~mm}$ less water per hectare per year than uneroded soils (Pimentel et al., 1995). In the tropics, Lal (1976) reported that erosion may reduce infiltration by upto 93\%. In addition to creating water deficiencies, soil erosion causes shortages of basic plant nutrients, such as nitrogen, phosphorus, potassium and calcium, which are essential for crop production. Sharma et al., (2001) reported that total nitrogen loss through eroded soil was $6.92 \mathrm{mg} / \mathrm{yr}$, organic carbon $50.54 \mathrm{mg} / \mathrm{yr}$ and total phosphorous $1.72 \mathrm{mg} / \mathrm{yr}$ from the watershed. The higher loss of total nitrogen through runoff was recorded from the cropped area while phosphate phosphorous from the forest land. When nutrient reserves are depleted by erosion, plant growth is stunted and crop yields decline. Soil that suffers severe erosion may produce $15 \%$ to 
$30 \%$ lower corn yields than uneroded soils (Pimentel et al., 1995). Under the current average soil erosion rates, the soil of nitrogen, phosphorus and potassium can expect to cause a long-term drop in crop yields.

Organic matters, a necessary component of soil, facilitate the formation of soil aggregates, increase soil porosity, and thereby improve soil structure, water infiltration and ultimately overall productivity. Fertile top soils typically contain about 100 tons of organic matter per hectare. Several studies have demonstrated that the soil removed by either with wind or water erosion is 1.3 to 5 times richer in organic matter than the soil left behind (Allison, 1973; Pimentel et al., 1995). Once the organic matter is depleted, soil productivity and crop yields decline because of the degraded soil structure and depletion of nutrients.

Although soil biotas are often ignored in assessment of the impact of erosion, they are critical component of the soil and constitute a large portion of the soil biomass. One square meter of soil may support population of about 200000 arthopods and enehytraeids and billion of microbes (Wood, 1989). A hectare of good quality soil contains an average of $1000 \mathrm{~kg}$ of earthworms, $1000 \mathrm{~kg}$ of arthopods, $150 \mathrm{~kg}$ of protozoa, $150 \mathrm{~kg}$ of algae, $1700 \mathrm{~kg}$ of bacteria, and $2700 \mathrm{~kg}$ of fungi (Pimentel et al., 1980). The tunneling and burrowing activities of earthworms and other soil biota enhance productivity by increasing water infiltration rates.

\section{DisCUSSION}

Watershed based hydrological studies was very limited in the Indian Himalayan region. So far in different landuse practices, we find that only forests have been studied in detail. Studies on other important land-uses such as agriculture, grassland, grazing land jhum cultivation and manipulating land-use/cover are limited. Most of these studies have observed run-off and soil loss only for rainy season. Pre-monsoon and winter season rainfalls, which may produce sizeable run-off, have not been studied.

In general, both stream-flow (range 1.12-76\%) and sediment transport (0.002-36.9tons $/ \mathrm{km}^{2} / \mathrm{yr}$ ) are not indicative of any trend in relation to watershed characteristics (Negi, 2002). Greater magnitude of soil loss in the Shiwaliks has been linked to immature geology and high degree of weathering of rocks. Overland flow and soil loss was greatest from the open cropped area because of intense cultivation on the mountain slopes. Soil loss as high 3005tons $/ \mathrm{km}^{2} / \mathrm{yr}$, were recorded in an agro-ecosystem under 5 years of shifting cultivation (Toky and Ramakrishnan, 1981).Therefore, land-use practice such as agroforestry $\left(280 \mathrm{mg} / \mathrm{km}^{2} /\right.$ yr) and stabilized cultivation $\left(1298 \mathrm{mg} / \mathrm{km}^{2} / \mathrm{yr}\right)$ were found better in terms reducing soil losses compared to shifting cultivation(Sharma et al., 2001). More than $72 \%$ of nutrient loss from the watershed was attributed to agricultural land-uses and therefore, intervention should focus upon these land-uses with emphasis on how to reduce the soil loss and measures to increase soil fertility (Sharma et al., 2001).

The limited number of studies available in this region, has on the one hand, documented the commonly perceived problem of soil loss and quick-flow of rainwater from the mountain slopes, blaming anthropogenic pressure and deforestation, and has provided simplistic and generalized recommendations such as plantation of broad leaf species, ban on grazing, deforestation and other human activities to crub the problem of soil and water erosion on the other. It can be emphasized that hydrological interventions on major land-use practices are required.

\section{Conclusion}

Soil erosion is a major environmental threat to the sustainability and productive capacity of land-use/covers. During the last 40 years, one third of the world's arable land has been lost by erosion and contributes to be lost 
at a rate of more than 10 million hectares per year. In the present watershed, a major proportion of the land-use/ cover is rainfed agriculture involving intensive cropping practices on open, unterraced slopes and agroforestry systems. Overland flow and soil loss were very high from open agriculture (cropped) fields compare to other land-uses in the watershed. Large cardamom based agroforestry and forest conserved more soil compared to open agricultural fields under traditional practices. This suggests an increase in soil and water conservation measures in the watershed. Such practices would help in soil and nutrient conservation consequently enhancing the soil fertility status and productivity. Soil and water conservation values of both large cardamom and broom grass were higher compared to other crops. These are perennial cash crops of greater conservation potential that could be more useful for extensive plantation in the event of large scale land-use change from forestry to agriculture. Therefore, there is a need for innovative technology measures for soil and water conservation in the region. We should heed U.S. President Roosevelt's warning that "A nation that destroys its soils, destroys itself".

\section{REFERENCES}

Allison, I.E. (1973) Soil Organic Matter and its Role in Crop Production. Elsevier, New York, USA.

Antle, J.M., Valdivia, R.O., Crissman, C.C., Stoorvogel, J.J. and Yanggen, D. (2004) Spatial heterogeneity and adoption of soil conservation investments: integrated assessment of slow formation terraces in the Andes. Montana State University. Bozeman MT.

Blackburn, W.H., Wood, J.C., and Dehaven, M. G. (1986) Storm flow and sediment losses from site-prepared forestland in East Texas. Water Resources Research. 22(5) 776-784.

Chambers, R. (1983) Rural Development: putting the poor first. Longman, London.

Collinson, M. (1984) Diagnosing the problems of small farmer needs, In: T. J. Davis (ed.) Proceedings of the $4^{\text {th }}$ Sector Symposium, World Bank, Washington, DC.

Hailu. Z. and Runge-Metzer, A. (1993) Sustainability of Land Use Systems: The potential of indigenous measures for the maintenance of soil productivity in sub-Saharan African agriculture. A review of methodologies and research results. Tropical Agroecology series No. 7, Verlag Josef Margraf.

Hudson, N. (1992) Land Husbandry. B. T. Batsford Limited, London. pp. 192.

ICIMOD (1994) Constraints and opportunities. Proceedings of the International Symposium on Mountain Environment and Development, International Centre for Integrated Mountain Development, Kathmandu, Nepal.

IFAD (1992) Soil and water conservation in Sub-Saharan Africa: Towards sustainable production by the rural poor. Centre for Development Cooperation Services, Free University, Amsterdam.

Joshi, D. (1997) Indigenous technical knowledge in Nepal, pp 45-61, In: Issue on Sustainable Land Management No. 3 (ed. Lesile, R.). International Board of Soil Research and Management (IBSRAM), Bangkok, Thailand.

Kerr, J and Sanghi, N.K. (1992) Indigenous soil and water conservation in India's semi-arid tropic. International Institute for Environment and Development, Gatekeeper series No. 34, London: IIED.

Lal, R. (1976) Soil Erosion Problems on an Alisol in Western Nigeria and their Control. International Institute of Tropical Agriculture, Ibadan, Nigeria.

Lutz, E., S. Pagiola, and Reiche, C. (1994) The costs and benefits of soil conservation: the farmers' viewpoint. The World Bank Research Observer 9(2): 273-295.

Mersereau, R.C. and Dyrness, C.T. (1972) Accelerated mass wasting after logging and slash burning in western Oregon, Journal of Soil and Water Conservation. 27:112-1 14. 
Milliman, J.D. and Meade, R.H. (1983) World-wide delivery of river sediments to the oceans. Journal of Geology. 91: 1-21.

Moffat, A.J. (1991) Forestry and soil protection in the UK, Soil Use Management. 7:145-151.

Negi, G.C.S. (2002) Hydrological Research in Indian Himalayan Mountains: Soil and Water Conservation. Current Science, 83(8): 974-980.

Patric, J.H. (1976) Soil erosion in the eastern forest. Journal of Forestry. 74: 671-676.

Pimentel, D.; C. Harvey; P. Resosudarmo; K. Sinclair; D. Kurz; M. McClair; S. Crist; L. Shpritz; L. Fitton; L. Saffouri, R. and Blair (1995) Environmental and Economic Costs of Soil Erosion and Conservation Benefits. Science, 267: 1117-1123.

Pretty, J. N. and Shah. P. (1994) Soil and Water Conservation in the Twentieth Century: a history of erosion and control. Research Series No. 1. University of Reading, Reading.

Rai, S.C. and Sharma, E. (1998) Comparative assessment of run-off characteristics under different land-use patterns within a Himalayan watershed. Hydrological Process 12: 2235-2248.

Rawat, J.S. and Rawat, M.S. (1994) Accelerated Erosion and Denudation in the Mankoshi Watershed, Central Himalaya, India, Part I: Sediment load. Mountain Research and development, 14 (1):25-38.

Reij, C., Turncr, S. D. and Kuhlmann, T. (1986) Soil and Water Conservation in Sub-Saharan Africa: issues and options. IFAD, Rome.

Richards, P. (1980) Community environmental knowledge. In: Indigenous Knowledge Systems and Development (eds. Brokensha, D.W., Warren, D.M. and Werner, O.) pp.183-196. University Press of America, Lahham, MD, USA.

Sharma, E. (2001) Absolute Advantage Resources as Potential Neutralizers of Globalization Risks. News Letter Mountain Risks and Hazards No. 40, Winter, 2001, ICIMOD, Kathmandu, Nepal.

Sharma, E., Rai, S.C. and Sharma, R. (2001) Soil, water and nutrient conservation in upland farming system: a case study of Sikkim Himalaya. Journal of Environmental Management, 61:123-135.

Sharma, E., Singh, K.K. and Sharma, G. (2000) Boon for mountain populations: large cardamom farming in the Sikkim Himalaya. Mountain Research and Development 20(2): 108-111.

Sidle, R.C. and Hornbeck, J. W. (1991) Cumulative effects: a broader approach to water quality research, Journal of Soil and Water Conservation. 46: 268-271.

Singh, J.S., Pandey, A.N. and Pathak, P.C. (1983) A hypothesis to account for the major pathways of soil loss from Himalaya. Environmental Conservation 10: 343-345.

Stoddart, D.R. (1969) World erosion and sedimentation in water. In: Water Earth and Man, (ed. R.J. Chorley), pp. 43-64. London: Methuen.

Toky, O.P. and Ramakrishnan, P.S. (1981) Cropping and yields in agricultural systems of the northeastern hill region of India. Agro-Ecosystems 7: 11-25.

UNEP/ISRIC (1990) World map on status of human induced soil degradation; scale 1:10,000,000. UNEP, Nairobi, Kenya.

Valdes, P.A. (1994) Economic analysis of soil conservation in Honduras. Environment paper No.8, pp. 63-74.The World Bank, Washington, DC. 
Valdiya, K.S. and Bartarya, S.K. (1989) Landslide and erosion in the Catchment of Gaula River, Kumaun Lesser Himalaya, India. Mountain Research and Development, 9: 403-419.

Warren,D.M. (1991) Using Indigenous Knowledge for Agricultural Development. World Bank Discussion Paper, 127, pp 46.

Willcocks, T. J., Twomlow, S. J., Ellis-Jones, J. and Critchley. W. R. S. (1992) Conserve Water to Save Soil and the Environment, Project Proposal Document, Overseas Division, AFRC, Silsoe Research Institute, Silsoe, UK.

Winters, P., Chrissman, C.C. and Espinosa, P. (2004) Inducing the adoption of conservation technologies: lessons from the Ecuadorian Andes. Environment and Development Economics 9: 695-719.

Wood, M. (1989) Soil Biology. Blackie, Chapman and Hall, New York, USA.

Citation: Dr. Prabuddh Kumar Mishra, "Assessment of Run-off and Soil Loss under different Land-use Practices in a Himalayan Watershed, India". American Research Journal of Humanities and Social Sciences, Volume 3, 2017; pp:1-10

Copyright (c) 2016 Dr. Prabuddh Kumar Mishra,, This is an open access article distributed under the Creative Commons Attribution License, which permits unrestricted use, distribution, and reproduction in any medium, provided the original work is properly cited. 